\title{
IKUT SERTA DALAM PROSES BELAJAR MENGAJAR DI SEKOLAH DASAR
}

\author{
Devi Novita Resky Fauzya \\ NIM: \\ 9173770410203 \\ Email: devinovitaresky@@gmail.com
}

\section{BentukKegiatan}

- Praktekmengajar

2. Lokasi

- SDN 67 Gantarang

- SDI 191Bontonompo

3. Hari/Tanggal danWaktu

- SDN 67 Gantarang( Setiap selasa dan rabu)

- SDI 191 Bontonompo (setiapsenin, kamis dan sabtu)

4. Peserta yangDilibatkan

- Mahasiswa KKLP STIE

\section{STKIP YAPTI}

- Murid-murid

\section{Alasan Diadakannya}

Kami mengadakan kegitaan magang mengajar ini dapat membantu kami selaku calon pendidik melatih diri sebagai calon pendidik.

6. Tujuan dan Manfaat Membiasakan diri kami berinteraksi denganpelajar/murid.Manfaatnya,kami bisa terbiasa berhadapan dan sudah mulai percaya diri menyampaikan materi pelajaran di depan paramurid.

\section{DeskripsiKegiatan}

Kegiatan ini kami lakukan di dua sekolah. Kami berangkat ke kedua sekolah tersebut dengan menggunakan 
motor karna jarak antara sekolahdengan posko kami lumayan jauh. Murid-murid di sekolah tersebut pun sangat aktif ketika kami mulai masuk ke kelasnya. Kami biasanya berangkat jam 8 pagi untuk mendapatkan jam pertama dan juga berangkat jam 10 untuk mendapatkan jam kedua di sekolah tersebut. 
8. ReferensiWajib

- HERIANTO,H.,\&Amir,A.S.(2020,September23).PedomanPelaksanaanKuliahKerja

Lapangan Plus (KKLP) Mahasiswa STIE dan STKIP YAPTI

Jeneponto.https://doi.org/10.31219/osf.io/7dvpk 


\title{
OBSERVASI LINGKUNGAN DI SETIAP DUSUN DI DESA GANTARANG
}

\author{
Devi Novita Resky Fauzya \\ NIM: \\ 9173370410203 \\ Email: devinovitareskyf@gmail.com
}

\section{BentukKegiatan}

- Kunjungan ke dusun-dusun se desa Gantarang selama 4hari

- Penentuan program kerja yang akan dipaparkan dalam seminar program kerja desaGantarang

2. Lokasi

- DusunSunggumanai

- Dusun BontoBiraeng

- Dusun BontoMarannu

- Dusun Gantarang Buleng

- DusunBontonompo

- Dusun MacciniBaji

- Dusun BontoBaru

3. Hari/Tanggal danWaktu

Rabu, 16 September 2020

- Dusun Sunggu Manai (09.00WITA)

- Dusun Bonto Biraeng (13.30WITA)

- Dusun Bonto Marannu ( 15.30 WITA)

Kamis, 17 September2020

- Dusun Gantarang Buleng (09.00 WITA)

- Dusun Bontonompo (13.00WITA)

- Dusun Maccini Baji (15.30WITA)

Jum'at, 18 September 2020

- Bonto Baru (08.00 WITA)

4. Peserta yangDilibatkan 
Kepala Dusun DesaGantarang

- Masyarakat

- Mahasiswa(i) STIE STKIP YAPTI JENEPONTO

\section{Alasan Diadakannya}

Alasan diadakannya observasi iniadalah untuk mengetahui apa saja yang akan menjadi program kerja kami selama dua bulan ke depan. Selain itu, tujuan observasi ini adalah untuk lebih mendekatkan tali silaturrahmi diantara masyarakat dengan mahasiswa KKLP yang awalnya belum saling kenal mengenal, bisa menjadi saling mengenal.

\section{Tujuan danManfaat}

Observasi atau kunjungan ini bermanfaat lebih memberi kami informasi mengenai desa Gantarang dan lebih saling mengenal dengan masyarakat setempat.

\section{DeskripsiKegiatan}

Kegiatan observasi ini dimulai padajam 09.00 di hari pertama berada di desa Gantarang. Kami melakukan observasi ini dengan berjalan kaki untuk dusun-dusun yang letaknya tidak jauh dari posko kami tapi untuk dusun-dusun yang letaknyajauh 
